\title{
Wiedza pielęgniarek i jej wykorzystanie w terapii bólu pooperacyjnego u pacjentów Oddziału Anestezjologii i Intensywnej Terapii
}

\author{
Nurses' knowledge and it's use in postoperative treatment of \\ pain in patients of the Anaesthesiology and Intensive \\ Therapy Ward
}

\author{
LEOKADIA REZMERSKA ${ }^{1}$, ILONA DULSKA ${ }^{2}$ \\ ${ }^{1}$ Państwowa Wyższa Szkoła Zawodowa we Włocławku, Instytut Nauk o Zdrowiu \\ ${ }^{2}$ Wojewódzki Szpital Zespolony w Płocku, Oddział Anestezjologii i Intensywnej Terapii
}

DOI: http://dx.doi.org/10.21784/IwP.2017.001

ISSN: 2451-1846

\section{Streszczenie:}

Wstęp. Ból pooperacyjny jest bólem ostrym o złożonej reakcji organizmu na uraz tkanek. Ból jest indywidualnym, subiektywnym doznaniem dlatego powoduje trudności w rzetelnej ocenie jego nasilenia. W codziennej praktyce szpitalnej stosowane są głównie odpowiednie skale oceny natężenia bólu, które są szybką, łatwą i czytelną formą jego oceny. Monitorowanie parametrów nasilenia bólu jest niezbędne do jego oceny i stanowi podstawę skutecznego leczenia. Postępowanie przeciwbólowe po zabiegach operacyjnych stanowi podstawowe działanie terapeutyczne wokresie pooperacyjnym. Wiedza, doświadczenie i kompleksowa opieka pooperacyjna realizowana przez pielęgniarkę zapewnia choremu zniesienie bólu, stresu pooperacyjnego oraz gwarantuje wysoką jakość świadczeń medycznych.

Cel. Celem badań była ocena poziomu wiedzy pielęgniarek i jej wykorzystania w terapii bólu pooperacyjnego u pacjentów Oddziału Anestezjologii i Intensywnej Terapii

Materiał i metody. Badania przeprowadzono w Wojewódzkim Szpitalu Zespolonym w Płocku. Grupę badaną stanowiło 81 pielęgniarek 
zatrudnionych w Oddziale Anestezjologii i Intensywnej Terapii. Badania przeprowadzono metodą sondażu diagnostycznego. Jako narzędzie badawcze wykorzystano kwestionariusz ankiety własnej konstrukcji.

Wyniki. Wykonane badania dowiodły, że pielęgniarki prezentują wysoki poziom wiedzy i jej wykorzystanie $\mathrm{w}$ zakresie terapii przeciwbólowej u pacjentów będących po operacji. Poziom ten zróżnicowany jest w zależności od czynników socjodemograficznych i zawodowych.

Wnioski. 1. Czynnikami wpływającymi na poziom wiedzy pielęgniarek i jej wykorzystanie $w$ terapii bólu pooperacyjnego u pacjentów są: wykształcenie pielęgniarek, ogólny staż pracy pielęgniarek wzawodzie, staż pracy pielęgniarek w Oddziale Anestezjologii i Intensywnej Terapii. 2. Czynnikami, które nie mają wpływu na poziom wiedzy pielęgniarek i jej wykorzystanie w terapii bólu pooperacyjnego u pacjentów są: wiek pielęgniarek i kwalifikacje zawodowe.

Słowa kluczowe: pielęgniarka, ból pooperacyjny, pacjent

\begin{abstract}
:
Introduction. Postoperative pain is an acute pain of a complex reaction of the body to a tissue in jury. Pain is an individual, subjective experience and there fore makes it difficult obtain a reliable assessment of its severity. In every day hospital practice, appropriate scales of pain intensity are mainly applied, which are quick, easy and legible form of pain assessment. Monitoring of pain intensity parameters is essential for its evaluation and is the basis for effective treatment. Pain management after surgery is a basic post operative therapeutic activity. Knowledge, experience and comprehensive post-operative care performed by the nurse provide the patient with the relief of pain, post-operative stress as well as guarantees high quality of medical services.

Aim. The aim of the study was to assess the level of nurses' knowledge and its use in the treatment of post operative pain in patients of the Ward of Anaesthesiology and Intensive Therapy

Material and methods. The study was conducted at the Provincial Hospital in Plock. The study group contained 81 nurses employedat the Ward of Anesthesiology and Intensive Therapy. The study was carried out by the diagnostic survey method. As a research tool, our own survey questionnaire was applied.
\end{abstract}


Results. Studies haves hown that nurses present a high level of knowledge and its use in the analgesic treatment of post operative patients. This level varies according to socio demographic and occupational factors.

Conclusions. 1. Factors influencing the level of nursing knowledge and its use in postoperative pain treatment in patients include: nurses' education, nurses' general occupational experience in nursing, nurses' occupational experience at the wards of Anesthesiology and Intensive Care. 2. Factors that do not affect nurses' knowledge and its use in the treatment of postoperative pain in patients include: nurses' age and their professional qualifications.

Keywords: nurse, postoperative pain, patient

\section{Wstęp}

Współczesna medycyna stwarza duże możliwości rozwiązywania problemów zdrowotnych poprzez zabiegi chirurgiczne. Każda ingerencja chirurgiczna wiąże się jednak z nieprzyjemnymi doznaniami zarówno dotyczącymi sfery fizycznej jak i psychicznej. Choremu towarzyszy wtedy lęk, strach, zdenerwowanie i przeświadczenie, że „musi boleć”. A przecież ból pooperacyjny nie jest zjawiskiem pożądanym i cierpienie chorego na pewno nie musi mu towarzyszyć. Pacjent ma prawo do uzyskania pełnych informacji na temat bólu pooperacyjnego i wyboru metod jego leczenia. Bólu pooperacyjnego nie należy bagatelizować. Nieprawidłowo leczony staje się niejednokrotnie przyczyną wielu powikłań pooperacyjnych. Konsekwencje niedostatecznego uśmierzania bólu pooperacyjnego mają zarówno wymiar indywidualny, taki jak cierpienie pacjenta, jak również społeczny i ekonomiczny $\mathrm{w}$ związku $\mathrm{z}$ wydłużonym czasem hospitalizacji. Sprzyjają powstawaniu zespołów przetrwałego bólu pooperacyjnego i depresji układu immunologicznego. Konsekwencje te wiążą się z pogorszeniem procesów gojenia rany, wzrostem ryzyka zakażeń oraz zwiększonymi kosztami leczenia i rehabilitacji pacjenta. Amerykańskie Towarzystwo Leczenia Bólu uznało ból za piąty parametr życiowy, co świadczy o tym, jak istotną rzeczą w praktyce klinicznej jest jego ocena i monitorowanie. Pomimo, że ból jest 
doznaniem wysoce subiektywnym, to jednak da się go zmierzyć i ocenić jego nasilenie [1].

Obecna specyfika pracy pielęgniarek w Oddziale Anestezjologii i Intensywnej Terapii nakłada na pielęgniarki posiadanie wielokierunkowej i kompleksowej wiedzy, która powinna być systematycznie udokumentowana kształceniem specjalistycznym. Pielęgniarka jako członek zespołu terapeutycznego, w terapii bólu pooperacyjnego pełni kluczową rolę wocenie pacjenta. To pielęgniarka spędza najwięcej czasu przy chorym i ma możliwość jego wnikliwej obserwacji. Od jej zdolności i umiejętnej, prawidłowej oceny intensywności i charakteru bólu zależy wgłównej mierze prowadzenie odpowiedniej diagnostyki i leczenia bólu pooperacyjnego. Posiadanie wiedzy z zakresu terapii bólu pooperacyjnego na właściwym poziomie i jej trafne wykorzystanie w pracy zawodowej, daje pielęgniarkom możliwość profesjonalnego diagnozowania bólu pooperacyjnego i udziału w terapii przeciwbólowej.

Celem badań była ocena poziomu i zakresu wiedzy pielęgniarek oraz jej wykorzystania w terapii bólu pooperacyjnego u pacjentów Oddziału Anestezjologii i Intensywnej Terapii.

\section{Materiał i metody}

Badania przeprowadzono w okresie od sierpnia do grudnia 2015 roku. W badaniach uczestniczyło 81 pielęgniarek pracujących w Oddziale Anestezjologii i Intensywnej Terapii w Wojewódzkim Szpitalu Zespolonym w Płocku. Na przeprowadzenie badań uzyskano zgodę Komisji Bioetycznej Uniwersytetu Mikołaja Kopernika w Toruniu, Collegium Medicum im. L. Rydygiera w Bydgoszczy (KB 398/2015). Dla wykonania badań wykorzystano metodę sondażu diagnostycznego $\mathrm{z}$ użyciem kwestionariusza ankiety własnej konstrukcji zawierającego 21 pytań zamkniętych jednokrotnego wyboru. Do zbadania zależności statystycznej pomiędzy analizowanymi cechami użyto testu chi kwadrat $\left(\chi^{2}\right)$ dla prób 
niezależnych. Obliczenia statystyczne wyników badań wykonano za pomocą pakietu statystycznego SPSS Statistica 21,0 z wykorzystaniem opracowanej dla potrzeb badań bazy danych programu Excel. Dla wszystkich analiz przyjęto współczynnik istotności na poziomie $\mathrm{p} \leq 0,05$.

\section{Wyniki}

W badaniach uczestniczyło 81 pielęgniarek, w wieku od 25 do 60 lat. Pod względem wykształcenia w grupie osób badanych dominowało wykształcenie wyższe na poziomie licencjata pielęgniarstwa. Największą grupę stanowiły pielęgniarki ze stażem pracy 15-29 lat. Natomiast najliczniejszą grupą pod względem stażu pracy w Oddziale Anestezjologii i Intensywnej Terapii była grupa pielęgniarek ze stażem 16-20 lat.

Tabela 1. Poziom wiedzy pielęgniarek na temat terapii bólu pooperacyjnego u pacjentów Oddziału Anestezjologii i Intensywnej Terapii.

\begin{tabular}{|l|r|r|}
\hline $\begin{array}{l}\text { Poziom wiedzy } \\
\text { pielegniarek }\end{array}$ & $\mathrm{n}$ & $\%$ \\
\hline niski poziom wiedzy & 5 & $6,17 \%$ \\
\hline średni poziom wiedzy & 21 & $25,93 \%$ \\
\hline wysoki poziom wiedzy & 55 & $67,90 \%$ \\
\hline
\end{tabular}

Źródło: wyniki badań własnych

Z analizy przeprowadzonych badań wynika, iż 67,9\% pielęgniarek wykazuje wysoki poziom wiedzy na temat terapii bólu pooperacyjnego u pacjentów Oddziału Anestezjologii i Intensywnej 
Terapii. Niespełna 26\% ankietowanych wykazuje średni poziom wiedzy, a jedynie $6 \%$ respondentek prezentuje niski poziom wiedzy.

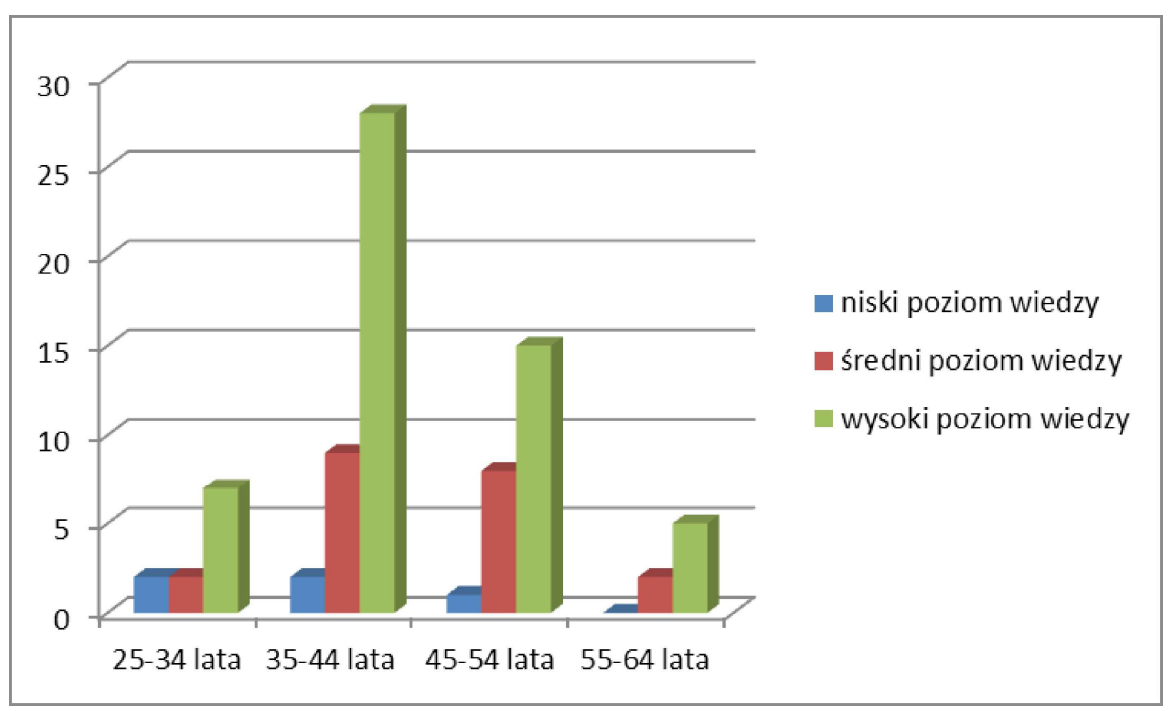

Rycina 1. Wiedza na temat terapii bólu pooperacyjnego u pacjentów Oddziału Anestezjologii i Intensywnej Terapii a wiek pielęgniarek.

Źródło: wyniki badań własnych

Analiza statystyczna nie wykazała istotnej zależności pomiędzy wiekiem ankietowanych a poziomem wiedzy na temat terapii bólu pooperacyjnego u pacjentów Oddziału i Anestezjologii i Intensywnej Terapii $\left(\chi^{2}=4,36, p=0,489\right)$. Zdecydowana większość respondentek bez względu na wiek wykazuje wysoki poziom wiedzy. 


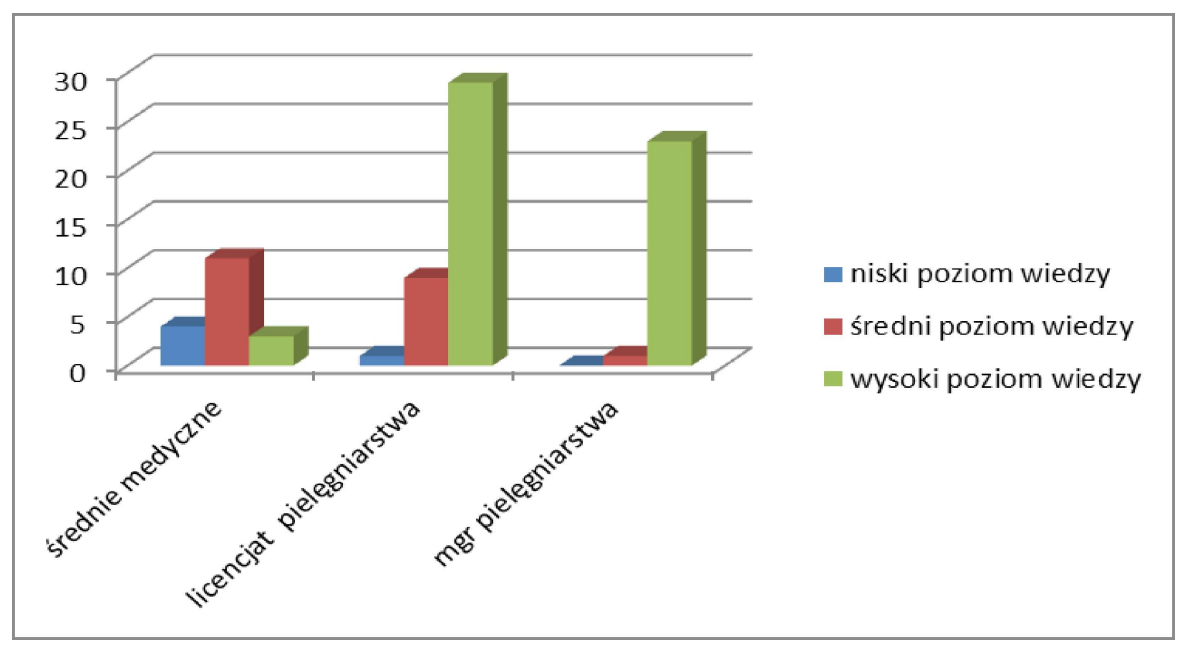

Rycina 2. Wiedza na temat terapii bólu pooperacyjnego u pacjentów Oddziału Anestezjologii i Intensywnej Terapii a wykształcenie pielęgniarek.

Źródło: wyniki badań własnych

Analiza statystyczna wykazała istotną zależność pomiędzy wykształceniem ankietowanych a poziomem wiedzy na temat terapii bólu pooperacyjnego u pacjentów Oddziału i Anestezjologii i Intensywnej Terapii $\left(\chi^{2}=32,87, p=0,020\right)$. Ponad 95\% respondentek z wykształceniem wyższym wykazuje wysoki poziom wiedzy. Natomiast ponad $61 \%$ ankietowanych $\mathrm{z}$ wykształceniem średnim medycznym wykazuje średni poziom wiedzy. 


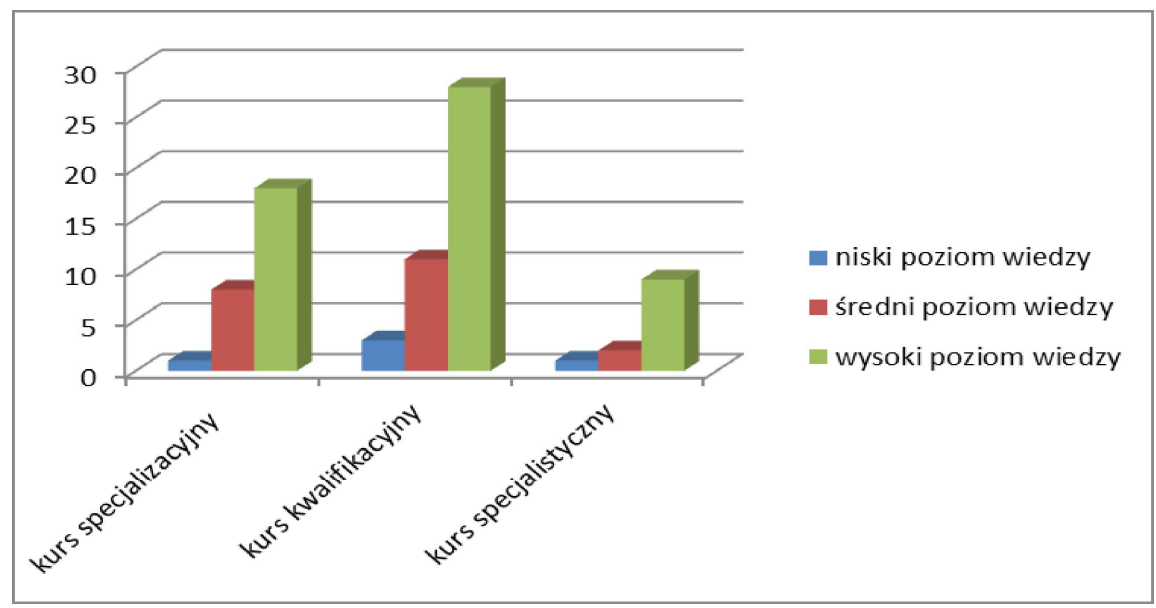

Rycina 3. Wiedza na temat terapii bólu pooperacyjnego u pacjentów Oddziału Anestezjologii i Intensywnej Terapii a posiadane kwalifikacje zawodowe pielęgniarek.

Źródło: wyniki badań własnych

W analizie statystycznej nie zaobserwowano istotnej statystycznie zależności pomiędzy kwalifikacjami zawodowymi ankietowanych a poziomem wiedzy na temat terapii bólu pooperacyjnego u pacjentów Oddziału i Anestezjologii i Intensywnej Terapii $\left(\chi^{2}=1,07, p=0,410\right)$. Zdecydowana większość respondentek bez względu na posiadane kwalifikacje wykazuje wysoki poziom wiedzy. 


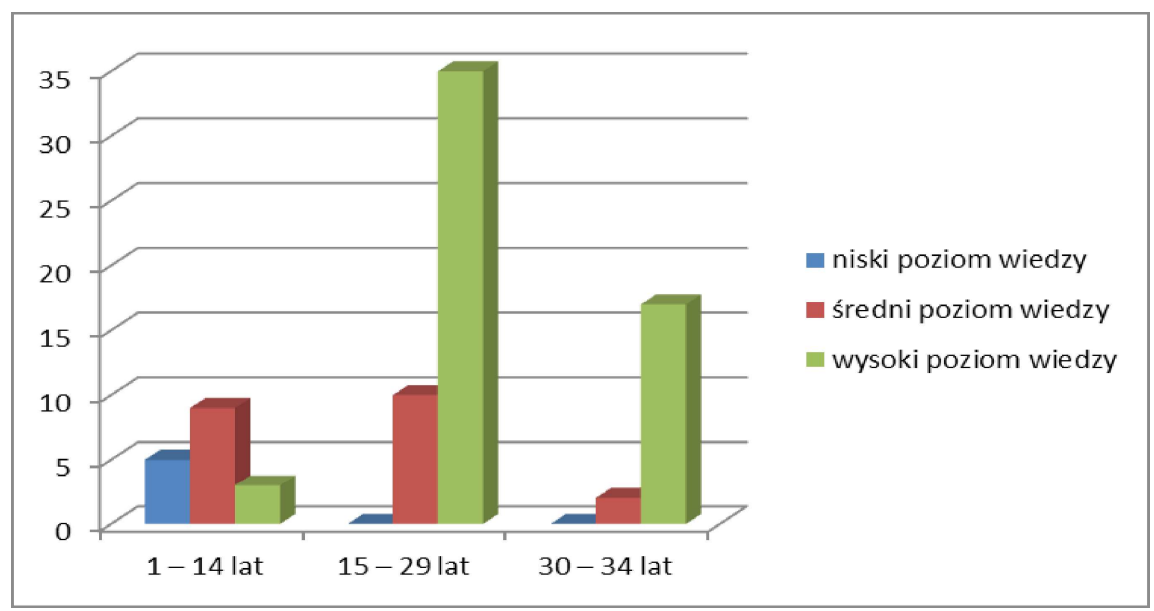

Rycina 4. Liczbowy rozkład wiedzy pielęgniarek na temat terapii bólu pooperacyjnego u pacjentów Oddziału Anestezjologii i Intensywnej Terapii a posiadany staż pracy pielęgniarek $w$ zawodzie.

Źródło: wyniki badań własnych

Analiza statystyczna wykazała istotną zależność pomiędzy stażem pracy w zawodzie ankietowanych a poziomem wiedzy na temat terapii bólu pooperacyjnego u pacjentów Oddziału i Anestezjologii i Intensywnej Terapii $\left(\chi^{2}=33,86, p=0,001\right)$. Ponad $89 \%$ respondentek pracujących w zawodzie 30-34 lata wykazuje wysoki poziom wiedzy. Natomiast ponad 52\% ankietowanych pracujących w zawodzie 1-14 lat wykazuje średni poziom wiedzy. 


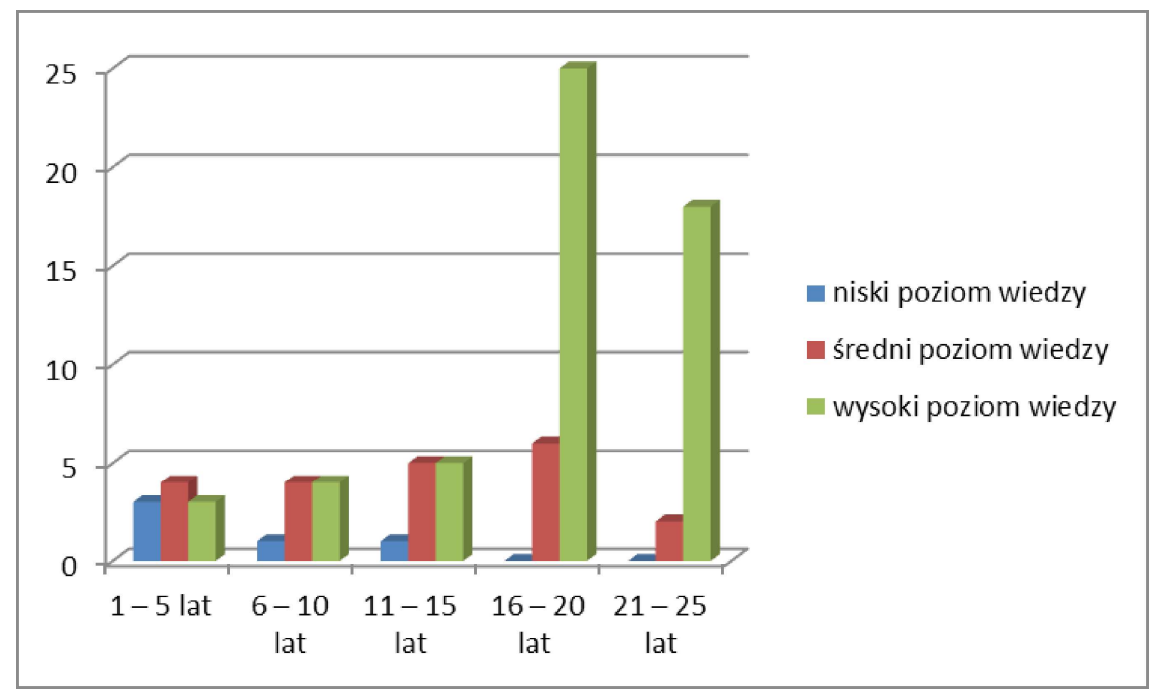

Rycina 5. Liczbowy rozkład wiedzy pielęgniarek na temat terapii bólu pooperacyjnego u pacjentów Oddziału Anestezjologii i Intensywnej Terapii a posiadany staż pracy pielęgniarek w Oddziale Anestezjologii i Intensywnej Terapii.

Źródło: wyniki badań własnych

Analiza statystyczna wykazała istotną zależność pomiędzy stażem pracy pielęgniarek w Oddziale Anestezjologii i Intensywnej Terapii a poziomem ich wiedzy na temat terapii bólu pooperacyjnego u pacjentów Oddziału i Anestezjologii i Intensywnej Terapii $\left(\chi^{2}=31,06, \quad p=0,011\right)$. Ponad $90 \%$ ankietowanych pracujących w Oddziale Anestezjologii i Intensywnej Terapii 21-25 lat wykazuje wysoki poziom wiedzy. Natomiast ponad $40 \%$ respondentek zatrudnionych w Oddziale Anestezjologii i Intensywnej Terapii 1-5 lat wykazuje średni poziom wiedzy. 


\section{Dyskusja}

Pomimo dynamicznego rozwoju badań nad bólem pooperacyjnym, który umożliwił poznanie jego mechanizmów oraz wprowadzenia nowoczesnych metod i środków wleczeniu, ból pooperacyjny uśmierzany jest $\mathrm{w}$ niedostatecznym stopniu aż u około $70 \%$ pacjentów. Z wyników badań PATHOS przeprowadzonych w latach 2004-2005 w 746 największych szpitalach w Austrii, Belgii, Francji, Niemczech, Portugalii, Hiszpanii i Szwajcarii wynika, że leczenie bólu pooperacyjnego nie jest prowadzone w sposób optymalny [2]. Z wielu badań dotyczących leczenia bólu pooperacyjnego wynika, że powyższy temat stanowi ciągle ważny i złożony problem. Skuteczne ograniczenie bólu pooperacyjnego i dostępność jego leczenia wymaga zaangażowania organizacyjnego poszczególnych szpitali, zespołu medycznego i specjalistycznej wiedzy medycznej.

Pielęgniarka w zespole terapeutycznym odgrywa istotną rolę w opiece nad chorym po zabiegu operacyjnym; ma ona bezpośredni, stały kontakt z pacjentem. Jej wiedza i trafne rozpoznanie problemów pacjenta odgrywa decydującą rolę w terapii bólu pooperacyjnego.

Analiza wyników badań własnych wykazała, że 67,9\% badanych pielęgniarek prawidłowo udzieliło odpowiedzi na pytania merytoryczne zawarte w ankiecie i wykazuje wysoki poziom wiedzy na temat bólu pooperacyjnego u pacjentów Oddziału Anestezjologii i Intensywnej Terapii. Niespełna $26 \%$ ankietowanych wykazuje średni poziom wiedzy, a jedynie $6 \%$ pielęgniarek wykazuje niski poziom wiedzy.

Wyniki badań własnych wykazują, że 87,7\% badanych pielęgniarek informuje pacjentów o możliwościach i różnych metodach uśmierzania bólu pooperacyjnego, 66,7\% ankietowanych dokonuje systematycznego pomiaru i monitowania bólu u pacjentów po zabiegach operacyjnych. Wśród badanej grupy pielęgniarek $86,4 \%$ prowadzi pisemną dokumentację postępowania przeciwbólowego u pacjentów w okresie okołooperacyjnym. Natomiast, w badaniach 
M. Knap, B. Szyrmer, B. Kowalczyk-Sroka uzyskano następujące wyniki: $23 \%$ badanych pielęgniarek monitoruje ból u swoich chorych, jedynie 30\% ankietowanych sporadycznie ocenia natężenia bólu, 45\% respondentów prowadzi dokumentację oceny natężenia bólu [3].

Wyniki badań własnych poddano również porównaniu z badaniami G. Bączyk, M. Ochmańskiej i S. Stępień, wykonanymi w Oddziale Chirurgii Ogólnej i Urazowej Samodzielnego Zakładu Opieki Zdrowotnej wŚwiebodzinie w 2006 roku. Badania te przeprowadzono wśród 100 chorych przy użyciu Skali Klinicznych Wskaźników Jakości Postępowania z Bólem. Zgodnie z założeniami autorów tej skali ogólna ocena jakości opieki pielęgniarskiej zawiera się w przedziale 14-70 punktów, gdzie minimalny wynik, który wyznacza właściwy poziom opieki pielęgniarskiej, nie powinien być mniejszy niż 63 punkty oraz 4,5 punktu w poszczególnych stwierdzeniach. Wyniki powyższych badań oceniają jakość opieki pielęgniarskiej dotyczącej bólu pooperacyjnego w punktacji ogólnej 60,84, czyli na średnim poziomie. Pacjenci uznali zastosowane metody leczenia bólu pooperacyjnego za skuteczne i ocenili je bardzo wysoko. Najwyższe oceny uzyskały podskale dotyczące zaufania i środowiska. Autorzy badań podkreślili pilną potrzebę ukierunkowania działań pielęgniarek i lekarzy na ilościową ocenę bólu przez personel, informowanie chorego o możliwościach leczenia bólu pooperacyjnego oraz współdecydowania chorego o metodzie leczenia bólu [4].

W badaniach własnych poddano analizie wiedzę pielęgniarek dotyczącą depresji oddechowej jako najpoważniejszego z objawów niepożądanych po podaniu opioidów. W wynikach $\mathrm{z}$ tego zakresu uzyskano $78,8 \%$ odpowiedzi prawidłowych. Dobrze opanowana wiedza dotyczącą objawów działań niepożądanych po podaniu opioidów dotyczyła także pielęgniarek biorących udział w badaniach przeprowadzonych przez M. Knap, B. Szyrmer, B. Kowalczyk-Sroka, gdzie aż 93\% ankietowanych wskazało prawidłową odpowiedź [3]. 
Autorzy powyższych badań, aby ocenić wiedzę pielęgniarek na temat terapii bólu pooperacyjnego poddali analizie ich udział w szkoleniach. Stwierdzono, że tylko $50 \%$ badanych uczestniczyło w szkoleniach wewnątrzszpitalnych o tematyce leczenia bólu. Takie same wyniki uzyskano podczas badań własnych, gdzie 50,6\% pielęgniarek potwierdziło regularne uczestniczenie w szkoleniach dotyczących leczenia bólu pooperacyjnego, a 53\% badanych potwierdziło, że wich miejscu pracy prowadzone są szkolenia dotyczące leczenia bólu pooperacyjnego. Powyższe wyniki wskazują na niewystarczający udział pielęgniarek w szkoleniach. Problematykę szkolenia pielęgniarek odnajdujemy także w badaniach M. Knap i R. Szebla. Autorzy tych badań podkreślili również niewystarczający udział personelu medycznego w szkoleniach dotyczących leczenia bólu pooperacyjnego, a także potrzebę szkolenia na poziomie kursów specjalistycznych, nadających pielęgniarkom uprawnienia do podawania leków różnymi drogami np. do przestrzeni zewnątrzoponowej [5].

Podczas badań własnych, stwierdzono, że 77,8\% respondentów jest zdania, iż w przypadku niewystarczającej analgezji w postaci niesteroidowych leków przeciwzapalnych i paracetamolu powinno się podać dożylnie opioid metodą PCA czyli analgezji stosowanej przez pacjenta. Przeciwko tej metodzie jest $16,0 \%$ badanych, a 6,2\% nie ma zdania na ten temat. Powyższe badania porównano z badaniami M. Knap i R. Szebla, gdzie jedynie 7\% badanych stosuje analgezję sterowaną przez pacjenta, 24\% badanych podaje leki w sposób systematyczny, a $23 \%$ podaje leki wtedy gdy chory skarży się na ból [5].

Badania własne porównano również z badaniami A. Raszki, A. Karabanowicz, M. Harata dotyczącymi zastosowania leczenia przeciwbólowego metodą PCA. Badania tego zespołu zostały przeprowadzone w Klinice Neurochirurgii Wojskowego Szpitala Klinicznego z Polikliniką w Bydgoszczy w 2010 roku a brało w nich udział 40 pacjentów. Z badań tych wynika, że zastosowanie leczenia 
przeciwbólowego sterowanego przez pacjenta za pomocą zaprogramowanej pompy infuzyjnej umożliwia dostosowanie dawki leku do indywidualnych potrzeb pacjenta, zminimalizowanie niewystarczającego działania przeciwbólowego oraz wyeliminowanie działań ubocznych związanych z przedawkowaniem leku. System PCA pozwala osiągnąć skuteczną analgezję oraz zmniejszyć czas leczenia przeciwbólowego. Większość badanych - 52,5\%- miało bardzo dobre odczucia po zastosowaniu pompy infuzyjnej z systemem PCA, 45\% dobre odczucia, nieznaczna część respondentów, bo tylko 2,5\% źle znosiło takie leczenie. Badani pacjenci wskazali na pozytywne aspekty korzystania z systemu PCA takie jak; brak bólu, wygoda, dobre samopoczucie, możliwość korzystania z dodatkowych dawek leku przeciwbólowego, niezależność [6].

\section{Wnioski}

1. Czynnikami wpływającymi na zakres wiedzy pielęgniarek i jej wykorzystanie w terapii bólu pooperacyjnego u pacjentów Oddziału Anestezjologii i Intensywnej Terapii są: wykształcenie pielęgniarek, ogólny staż pracy w zawodzie, staż pracy w Oddziale Anestezjologii i Intensywnej Terapii.

2. Czynnikami, które nie mają wpływu na zakres wiedzy pielęgniarek i jej wykorzystanie w terapii bólu pooperacyjnego u pacjentów Oddziału Anestezjologii i Intensywnej Terapii są: wiek pielęgniarek i kwalifikacje zawodowe.

\section{Zalecenia dla praktyki pielęgniarskiej}

Dla zapewnienia wysokiej jakości opieki pielęgniarskiej niezbędne jest systematyczne podnoszenie poziomu wiedzy i doskonalenie kwalifikacji zawodowych pielęgniarek w zakresie terapii bólu pooperacyjnego. Zalecenie to szczególnie dotyczy starszej grupy wiekowej pielęgniarek, jak również posiadających wykształcenie średnie medyczne oraz z krótkim stażem pracy 
w zawodzie i krótkim stażem pracy w Oddziale Anestezjologii i Intensywnej Terapii.

\section{Bibliografia/Bibliography:}

1. Kapała W.: Ocena i leczenie bólu pooperacyjnego i pourazowego ujęcie kliniczne i pielęgniarskie [w:] Bączyk G., Kapała W. (red.): Podstawy kliniczne oraz pielęgnowanie chorych wokresie przedi pooperacyjnym w chirurgii ogólnej, ortopedii i traumatologii. Wyd. Uniwersytet Medyczny. Poznań 2012:240.

2. Wordliczek J.: 0 praktyce walki z bólem. Rynek Zdrowia. 2009;2:4.

3. Knap M., Szyrmer B., Kowalczyk-Sroka B.: Poziom wiedzy pielęgniarek z oddziałów zabiegowych na temat terapii bólu pooperacyjnego. Problemy Pielęgniarstwa. 2010;18(2):130.

4. Bączyk G., Ochmańska M., Stępień S.: Subiektywna ocena jakości opieki pielęgniarskiej w zakresie bólu pooperacyjnego u chorych leczonych chirurgicznie. Problemy Pielęgniarstwa. 2009;17:175-176.

5. Knap M., Szebla R.: Rola pielęgniarek w zespołach leczenia bólu jako profesjonalnej terapii bólu pooperacyjnego. Studia Medyczne. 2011;22:42.

6. Raszka A., Karabanowicz A., Harat M.: Metoda PCA w zwalczaniu bólu w pierwszej dobie po operacji kręgosłupa. Pielęgniarstwo Neurologiczne i Neurochirurgiczne. 2013;2,61-62. 